\title{
Mathematics literacy skills in pre-service teachers: What could they do?
}

\author{
Afit Istiandaru*, Puguh Wahyu Prasetyo, Vita Istihapsari \\ Universitas Ahmad Dahlan, Jl. Ahmad Yani, Tamanan, Bantul, DIY 55711, Indonesia \\ *Corresponding E-mail: afit.istiandaru@pmat.uad.ac.id
}

ARTICLE INFO

Article History

Received 15 March 2021

Revised 24 March 2021

Accepted 24 March 2021

Keywords

Mathematics literacy

PISA

Pre-service teacher

How to cite this article: Istiandaru, A., Prasetyo, P. W., \& Istihapsari, V. (2021).

Mathematics literacy skills in preservice teachers: What could they do? Bulletin of Applied Mathematics and Mathematics Education, 1(1), 31-38.

\section{ABSTRACT}

Mathematics literacy is individual capacity to formulate, to employ, and to interpret mathematics in various contexts. Indonesian students aged 15 are required to perform these three skills and these abilities reflect the success of the curriculum. The results, however, are never considered satisfying since, many argue, the students are not accustomed to deal with the mathematics literacy problems. Teacher is then the one who takes the responsibility to make the students familiar with the literacy problems. This research aims to look closer at the mathematics literacy skills possessed by preservice teachers. It is a qualitative research which involved 128 undergraduate student teachers as the subjects. A custom mathematics literacy test was developed with various contexts to measure the student teachers' literacy skills according to the PISA framework. The results suggest that they performed well in the level 1 to 3 problems, but not in the level 4 to 6 . Many errors made by the student teachers in the stage of formulating, employing, or interpreting. Finally, teachers need to be accustomed to this skill before they are ready enough to teach their students.

This is an open access article under the CC-BY-SA license.

\section{Introduction}

Mathematics literacy is individual capacity to formulate, to employ, and to interpret mathematics in various contexts, such as personal, occupation, society, and science contexts (OECD, 2010). The Programme for International Students Assessment (PISA) regularly assesses the 15-year-oldstudents' performance in mathematics literacy and reports it to the participating countries. Indonesia also takes part in sending delegates to the assessment. The results, however, are never considered satisfying since, many argue, the students are not accustomed to deal with the mathematics literacy problems (Argina et al., 2017).

In the six times PISA assessment since 2000, Indonesia ranked in bottom ten. It ranked 39 of 41 in 2000, 38 of 40 in 2003, and 50 of 57 in 2006 (NCES, 2018). In 2009, Indonesian students ranked 57 of 65 countries, ranked 64 of 65 countries in 2012 and ranked 64 of 72 countries in 2015. In 2018, Indonesia ranked 73 of 79 countries (Schleicher, 2019). In detail, the PISA report suggests that it was only $28 \%$ of Indonesian students who successfully solved the problems at Level 2 or higher (Avvisati et al., 2019). The problem at Level 2 is described as showing skills of interpreting 
and recognizing situation in mathematical representation. On the contrary, the rest $72 \%$ could not reach this level. Therefore, Indonesian government regards the PISA results as the external challenge which triggers the reformation of Indonesian curriculum (MOEC, 2016).

Many factors cause the low performance of Indonesian students on PISA. Zulkardi \& Santoso (2015) suggest that the cause of the low PISA results of Indonesian students is the large number of test materials on PISA that are not included in the education curriculum in Indonesia. Indonesian students are not familiar with PISA-type questions (Aida et al., 2017), have not been accustomed to practicing with questions that require higher order thinking skills (Hartini et al., 2018), and have not obtained learning experiences that explore reasoning skills (Styawati \& Nursyahida, 2017). The mathematics teacher must strive for these habituations.

The teacher is one of the important factors in determining the success of a learning process (Ismail, 2010). Teachers must be able to facilitate students to become familiar with questions that require reasoning, higher order thinking, and questions that hone mathematical literacy skills. To be able to get students used to learning with questions of the PISA type, a teacher must have the ability to develop questions of the PISA type (Istiandaru, 2014). Furthermore, teachers must also have good mathematical literacy skills.

To have good mathematical literacy skills, a teacher must practice from the time of his education. This is based on the fact that there are not many teachers who are capable and eager to learn new things after getting a stable job. The enthusiasm for learning new things generally appears while still in college (continuing studies) or pursuing a continuous professional development program. Therefore, familiarizing prospective mathematics teacher students to be familiar with mathematics literacy problems is important.

The mathematics education department of Universitas Ahmad Dahlan has 533 prospective mathematics teacher students in the 2019/2020 academic year. The discussion about mathematics literacy and PISA generally happens in the courses of Junior High School Mathematics Curriculum Analysis and Mathematics Learning Process Evaluation. Furthermore, there has been no research that has measured overall mathematical literacy skills covering all PISA content and using a context adapted to UAD mathematics education students. The existing research has only measured mathematical literacy skills in space and shape content using the PISA instrument which should be intended for 15-year-old with a sample of one class (Hendroanto et al., 2018).

Therefore, a special study is needed regarding the mathematical literacy abilities of students of the UAD mathematics education study program as a whole both in terms of content and sampling by adopting the PISA framework, in order to obtain a more accurate picture of the literacy abilities of prospective mathematics student teachers.

\section{Method}

This research is a qualitative research. The subjects of this study were students of the mathematics education department of Universitas Ahmad Dahlan enrolled in 2020. They were selected conveniently representing each active batch. During the process of data collection, we have 128 student teachers joined the test.

We developed a mathematics literacy ability test by paying attention to the context, content, competence, level, and process of mathematical literacy by adopting PISA framework with selected context aspects that are familiar to the research subject and content taken from school mathematics topics. The test instrument was validated by two experts of mathematics literacy and they confirmed the validity of the test to measure the mathematics literacy ability.

The test was then given to the research subjects and analyzed descriptively. Furthermore, the 
researcher took a sample works of research subjects to be analyzed deeper. We tried to find out what the student teachers can do dealing with the mathematics literacy process of formulating, employing, and interpreting mathematics problems.

\section{Results and Discussion}

The results of the test are presented in Table 1.

Table 1. Descriptive results of the mathematics literacy test

\begin{tabular}{lcccccc}
\hline Percentage of students performing: & \multicolumn{4}{c}{ Level } & \multicolumn{3}{c}{ VI } \\
Process skills of math literacy & I & II & III & IV & V & 33.3 \\
\hline Formulating & 66.7 & 66.7 & 66.7 & 11.1 & 44.4 & 33.3 \\
Employing & 55.6 & 38.9 & 50 & 5.56 & 11.1 & 3.1 \\
Interpreting & 55.6 & 61.1 & 55.6 & 11.1 & 22.2 & 27.8 \\
\hline
\end{tabular}

Based on Table 1, we know that the student teachers were good to solve problems Level 1, 2, and 3. However, they mostly failed to solve problems Level 4, 5, and 6. This is in line with finding of Avvisati et al. (2019) who found that the Indonesian students could only deal with Level 2, no higher.

At the problem Level 1, more than half of the student teachers were successful to formulate the problem, employ their strategy and interpret the result. Problem level 1 said,

[THROWING DICE] What is the probability of getting the same dots in a throwing two dice together at once?

The problem Level 1 just needs a direct inference. Students need to think about all possible outcomes of throwing two dice at once and the number of possibilities to get two same dots. Then, calculate the ratio. Yet, there were almost a half of the students failed to solve it. Here we present the work of Subject E-10.

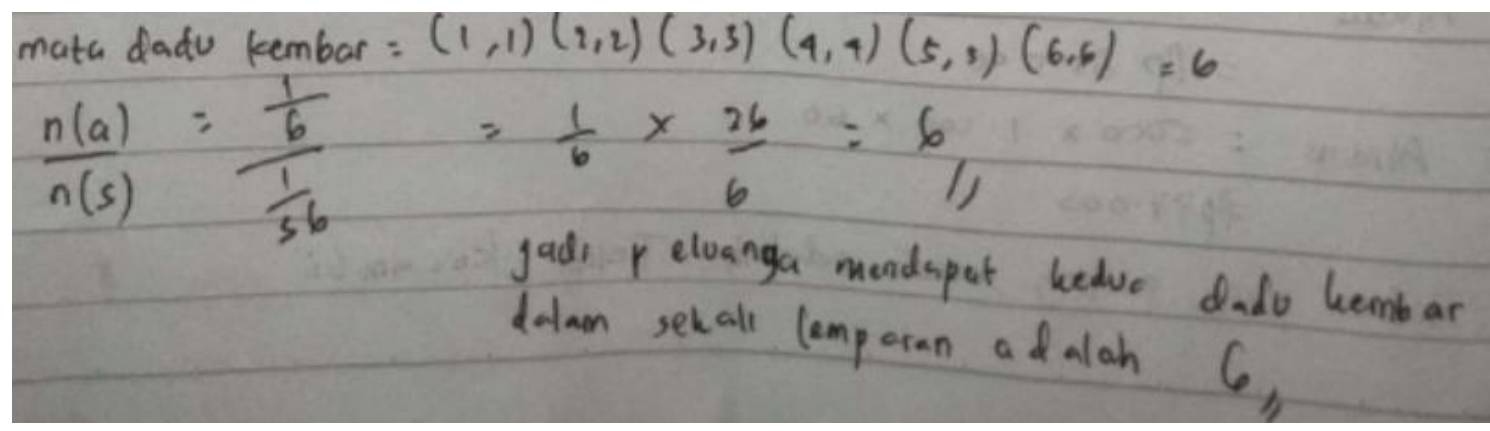

Figure 1. Sample work of E-10.

E-10 had a good start by identifying the all possibilities to get similar dots of two dice. But then E-10 failed to calculate the probability. Since the value of probability is no more than 1 , then the interpretation of the results was wrong if E-10 got 6 .

The problem Level 2 also shows a good start of formulating and interpreting, but most of student teachers failed in calculating properly. Problem Level 2 said, 
[BACTERIA] A bacteria splitting to be two individuals every 20 minutes. In a lab, there are 1,000,000 bacteria at the beginning of an observation. Estimate the number of bacteria right after 3 hours!

Towards the problem, students need to think about finding the $\mathrm{n}$-th term of a geometric sequence. In fact, some students cannot recognize nor build up the pattern. Thus, they arrived at a wrong solution, as presented in Figure 2.

$\begin{aligned} 1 \text { jam pertama } & =1.000 .000 \times 2 \times(60 \text { menit }: 20 \text { menit }) \\ & =1.000 .000 \times 2 \times 3 \\ & =6.000 .000 \text { bakten. } \\ \text { setelah 3 jäm } & =6.000 .000 \times 3 \\ & =18.000 .000 \text { bakten. }\end{aligned}$

Figure 2. Sample work of E-1.

E-1 simply multiplied the initial number of bacteria, the number of splitting, and the frequency of the splitting, without considering that each of the splitting bacteria would also split. This is a proof that there are still students out of logic in dealing with context.

Problem Level 3 requires students to work with procedural problems and select the best strategy. Problem Level 3 said,

[FARM HOUSE] A cube farm house has a $14 \mathrm{~m}$ height. Its roof is a pyramid having $24 \mathrm{~m}$ height. A farmer wants to cover it with asbestos sheets. Each sheet has $75 \mathrm{~cm} \times 200 \mathrm{~cm}$ length and width. If the farmer buys 460 sheets, is it enough to cover his entire roof?

Problem Level 3 requires students to sequentially perform procedural works. They have to work with Pythagorean theorem to find the altitude of each lateral face of the pyramid-shape roof, calculate its entire area, and then compare with the supply to decide if it is enough or not. Figure 3 provides the sample solution done by A-2.

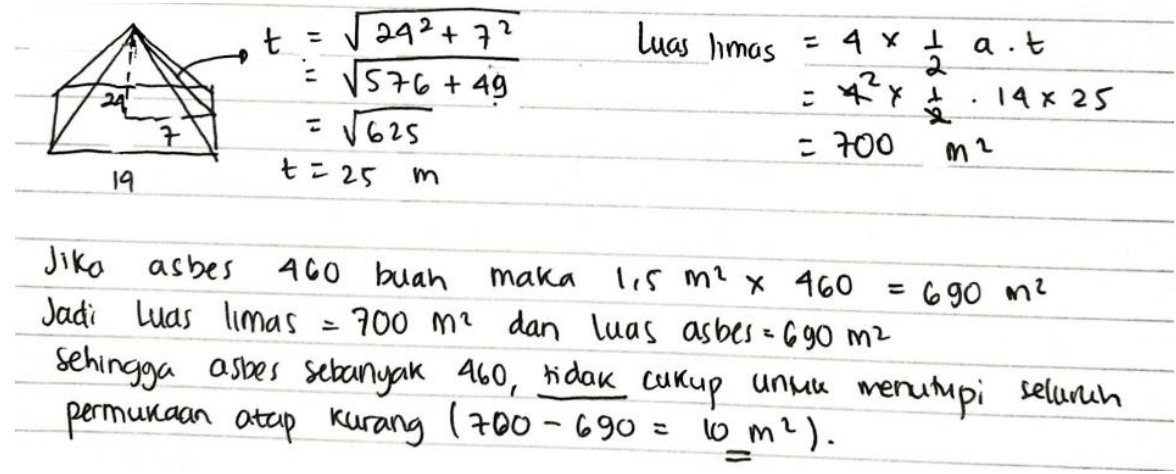

Figure 3. Sample work of A-2.

A-2 was good at formulating the problem, sketching the situation, employing the strategy, and making decision based on the calculation. 
Problem Level 4 requires the use of representation to work effectively. The problem said,

[SNAIL] A snail claim a 10-meter tree. It could claim 3 meters at daylight, but at night, it falls 2 meters. If it persistently climbs every daylight, what day it could reach the top of the tree?

Towards the problem, B-1 provide the answer as shown in Figure 4.

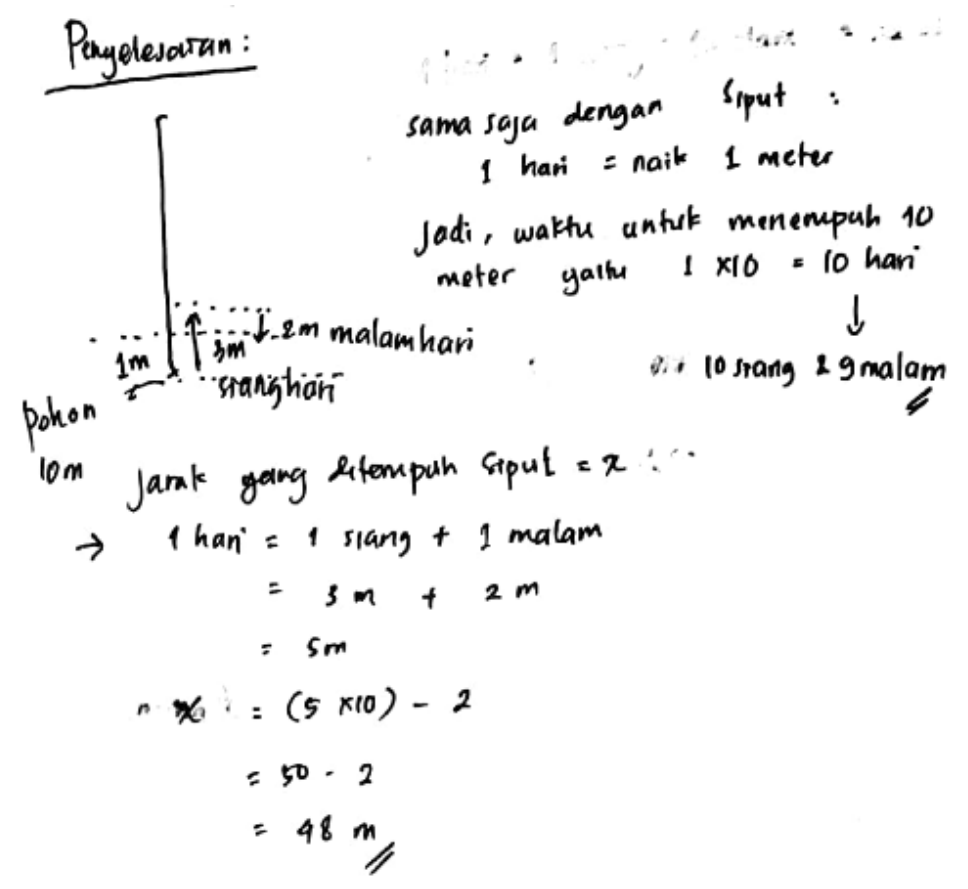

Figure 4. Sample work of B-1.

B-1 has sketch the snail path day by day correctly. It can be seen with the climbing arrow represents 3 meters and down arrow representing 2 meters. However, in the calculation of the path. It was written addition instead of subtraction. B-1 seems forget or did not understand about the concept of negative number. Therefore, B-1 arrived in a wrong answer.

Problem Level 5 demand the students to make assumptions, different representations, and evaluate their strategies. This problem said,

[SETTING A CAMP] A group of scout consists of 12 members want to set a tent with length $6 \mathrm{~m}$. The area of the roof is $24 \mathrm{~m} 2$. Help the group to set the tenth by suggesting the proper height and width of the tent such that all members could sleep inside it.

Towards this problem, A-3 provided answer as presented in Figure 5. 


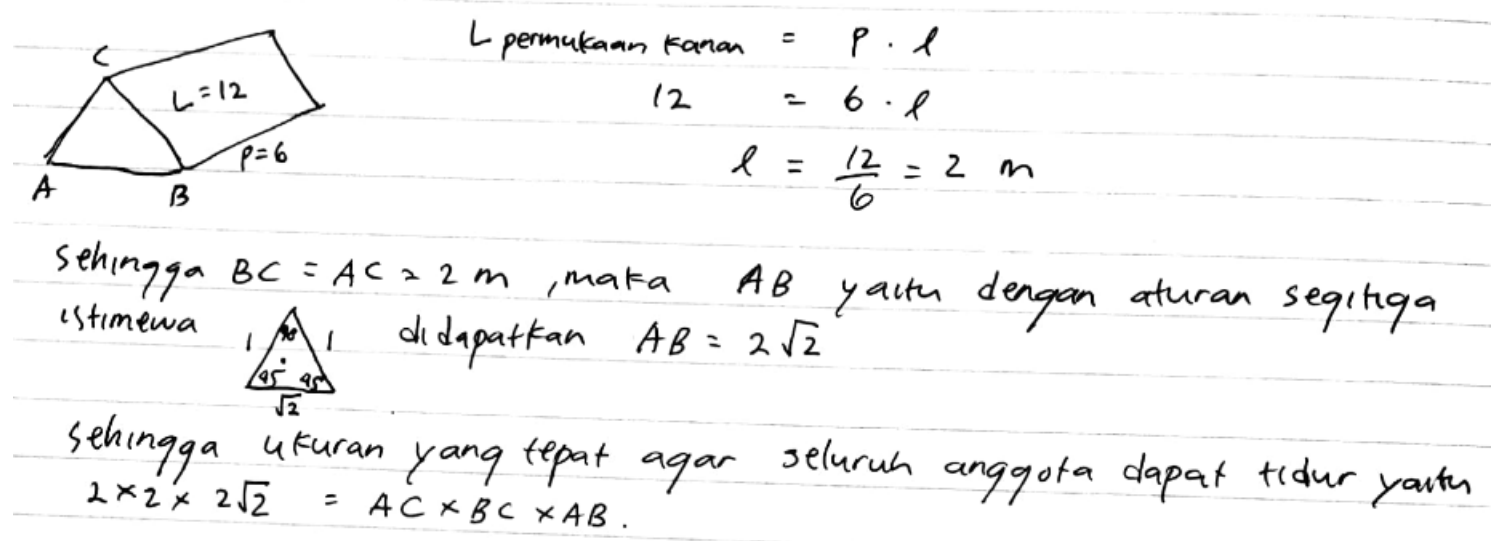

Figure 5. Sample work of A-3.

A-3 tried to sketch the situation and provided an alternative right triangle for the base of prism using the relationship of three special angle in a right isosceles triangle. The formulating and employing process is quite good but it lacks of reasoning on why chose this strategy. For instance, A-3 should also verify if the height is good enough for average men to stand inside the tent.

At last, the problem Level 6 requires students to make a guess or generalization based on model. The problem Level 6 said,

[ANTIBIOTIC] Every hour, an antibiotic will remain only $40 \%$ of the amount at the previous hour after injection to a body. If someone get $100 \mathrm{mg}$ antibiotic shot at 8.30, what time does the amount of antibiotic below $1 \mathrm{mg}$ ?

Towards this problem, E-8 provided answer as presented in Figure 6.

\begin{tabular}{l} 
(2) Penicillin \\
$8.30-100$ migram \\
\hline $9.10-40 \mathrm{mlgram}$ \\
\hline $9.50-16 \mathrm{~m}$ gram \\
$10.30-6,4 \mathrm{mlgram}$ \\
$11.10-2,56 \mathrm{mlgram}$ \\
\hline $11.50-1,024$ migram \\
$12.30-0,40$ g6 mlgram \\
\hline tadi penicilim mencapai < 1 megram pada pukul 12.30.
\end{tabular}

Figure 6. Sample work of E-8.

E-8 tried to make a sequence of the amount of antibiotic inside the body, but there is no explanation how to get it though the guess is quite correct. However, critics can be delivered because at 11.50 the amount of the antibiotic almost below $1 \mathrm{mg}$, while at 12.30 it is far below $1 \mathrm{mg}$. It is still make sense to say that it is not until 12.30 the antibiotic already less than $1 \mathrm{mg}$, probably right after 11.50. An adequate reasoning would make the answer better. 


\section{Conclusion}

Finally, we get an insight that the pre-service teachers were quite good at performing formulation, employing, and interpretation of PISA-like mathematics tasks at Level 1 to 3. However, many failed to perform the skills at Level 4 to 6 . These skills must be trained more often to give them provision for teaching at high school.

\section{Acknowledgement}

We thank the LPPM UAD for providing the research grant under the scheme of Penelitian Dasar 2020.

\section{References}

Aida, N., Kusaeri, K., \& Hamdani, S. (2017). Karakteristik instrumen penilaian hasil belajar matematika ranah kognitif yang dikembangkan mengacu pada model PISA. Suska Journal of Mathematics Education, 3(2), 130-139.

Argina, A. W., Mitra, D., Ijabah, N., \& Setiawan, R. (2017). Indonesian PISA result: What factors and what should be fixed? Proceedings Education and Language International Conference (Vol. 1, No. 1). Semarang: Unissula.

Avvisati, F., Echazarra, A., Givord, P., \& Schwabe, M. (2019). Results from PISA 2018: Country note Indonesia. Retrieved from: https://www.oecd.org/pisa/publications/PISA2018_CN_IDN.pdf.

Hartini, T., Misri, M. A., \& Nursuprianah, I. (2018). Pemetaan HOTS Siswa Berdasarkan Standar PISA DAN TIMSS untuk Meningkatkan Mutu Pendidikan. Eduma: Mathematics Education Learning and Teaching, 7(1), 83-92.

Hendroanto, A., Istiandaru, A., Syakrina, N., Setyawan, F., Prahmana, R. C. I., \& Hidayat, A. S. E. (2018). How Students Solves PISA Tasks: An Overview of Students' Mathematical Literacy. International Journal on Emerging Mathematics Education, 2(2), 129-138.

Ismail, M. I. (2010). Kinerja dan kompetensi guru dalam pembelajaran. Lentera Pendidikan: Jurnal Ilmu Tarbiyah dan Keguruan, 13(1), 44-63.

Istiandaru, A. (2014). PBL Pendekatan Realistik Saintifik dan Asesmen PISA untuk Meningkatkan Kemampuan Literasi Matematika. Unnes Journal of Mathematics Education Research, 3(2).

MOEC. (2016). Standar Kompetensi Lulusan Pendidikan Dasar dan Menengah. Jakarta: Ministry of Education and Culture.

NCES. (2018). Programme of International Students Assessment. Washington DC: National Center for Education Statistics. Retrieved from: https://nces.ed.gov/surveys/pisa/.

OECD. (2010). PISA 2012 Mathematics Framework. Paris: OECD Publications. Retrieved from: http://www.oecd.org/dataoecd/8/38/46961598.pdf.

Schleicher, A. (2019). PISA 2018: Insights and Interpretations. OECD Publishing.

Styawati, R. D., \& Nursyahida, F. (2017). Profil Kemampuan Literasi Matematika Siswa Berkemampuan Matematis Rendah Dalam Menyelesaikan Soal Berbentuk PISA. AKSIOMA: Jurnal Matematika dan Pendidikan Matematika, 8(2), 33-42.

Zulkardi, Z., \& Santoso, B. (2015). Kajian Soal Buku Teks Matematika Kelas X Kurikulum 2013 Menggunakan Framework PISA. Jurnal Pendidikan Matematika, 9(2), 188-206. 
BAMME Vol. 1 No. 1, April 2021, pp. 31-38

This page is intentionally left blank. 